\title{
LOADING AND UNLOADING RESIN FROM MPPF RAPID ION EXCHANGE COLUMNS
}

W. C. NG
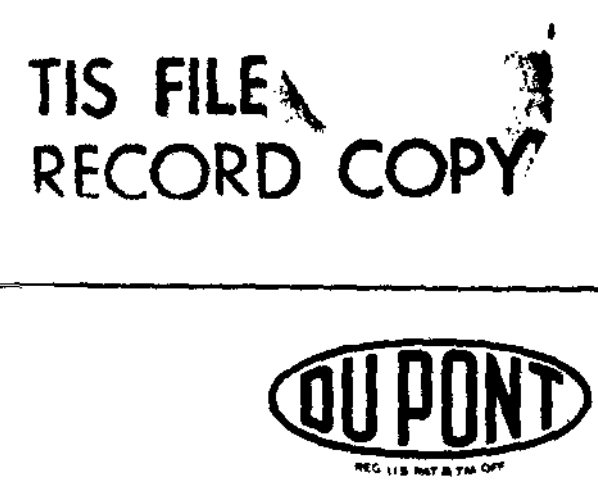

E. I. du Pont de Nemours \& Co. Savannah River Laboratory

Aiken, SC 29808 


\section{DISCLAIMER}

This report was prepared by E. I, du Pont de Nemours and Company (Du Pont) for the United States Department of Energy under Contract DE.ACO9.76SR00001 and is an account of work performed under that Contract. Neither the United States, the United States Department of Energy nor Du Pont, nor any of their employees, makes any warranty, express or implied, or assumes any legal liability or responsibility for the accuracy, completeness, or usefulness of any information, apparatus, product, or process disclosed herein, or represents that its use will not infringe privately owned rights. Reference herein to any specific commerical product, process, or service by trade name, mark, manufacturer, or otherwise does not necessarily constitute or imply endorsement, recommendation, or favoring of same by Du Pont or by the United States Government or any agency thereof. The views and opinions of authors expressed herein do not necessarily state or reflect those of the United States Government or any agency thereof.

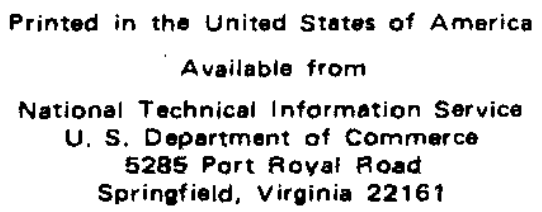

Price: Printed Copy A02; Microfiche AO1 
DP. 1609

Distribution Category: UC-38

\section{LOADING AND UNLOADING RESIN FROM MPPF RAPID ION EXCHANGE COLUMNS}

W. C. $\mathrm{Ng}$

Approved by: H. D. Harmon, Research Manager

Actinide Technology Division

Publication Date: October 1981

E. 1. du Pont de Nemours \& Co.

Savannah River Plant and Laboratory

Aiken, SC 29808

PREPARED FOR THE U. S. DEPARTMENT OF ENERGY UNDER CONTRACT DE.ACO9.76SR00001 
A process was developed which permits changing the resin in the Multipurpose Processing Facility Rapid Ion Exchange columns, without replacing the entire column as sembly. The columns remain on the rack during the resin removal and replacement. The resin displacement process consists of a resin unloading and a resin loading step. During resin removal, the spent resin is hydraulically displaced from the columns to a resin collection tank, and then transferred to the evaporator for dissolution. Fresh resin is loaded into the empty column by hydraulic displacement or a combination of vacuur loading followed by hydraulic displacenent. In the hydraulic displacement loading process, the amount of fresh resin needed to load the columns is transferred to a resin displacement tank where the resin is hydraulically displaced to the appropriate column. In the vacuum loading process, part of the resin feed is loaded directly into the colum by applying a negarive pressure to the column. After the columa is partially loaded, it is then loaded to its full capacity by hydraulic loading. 


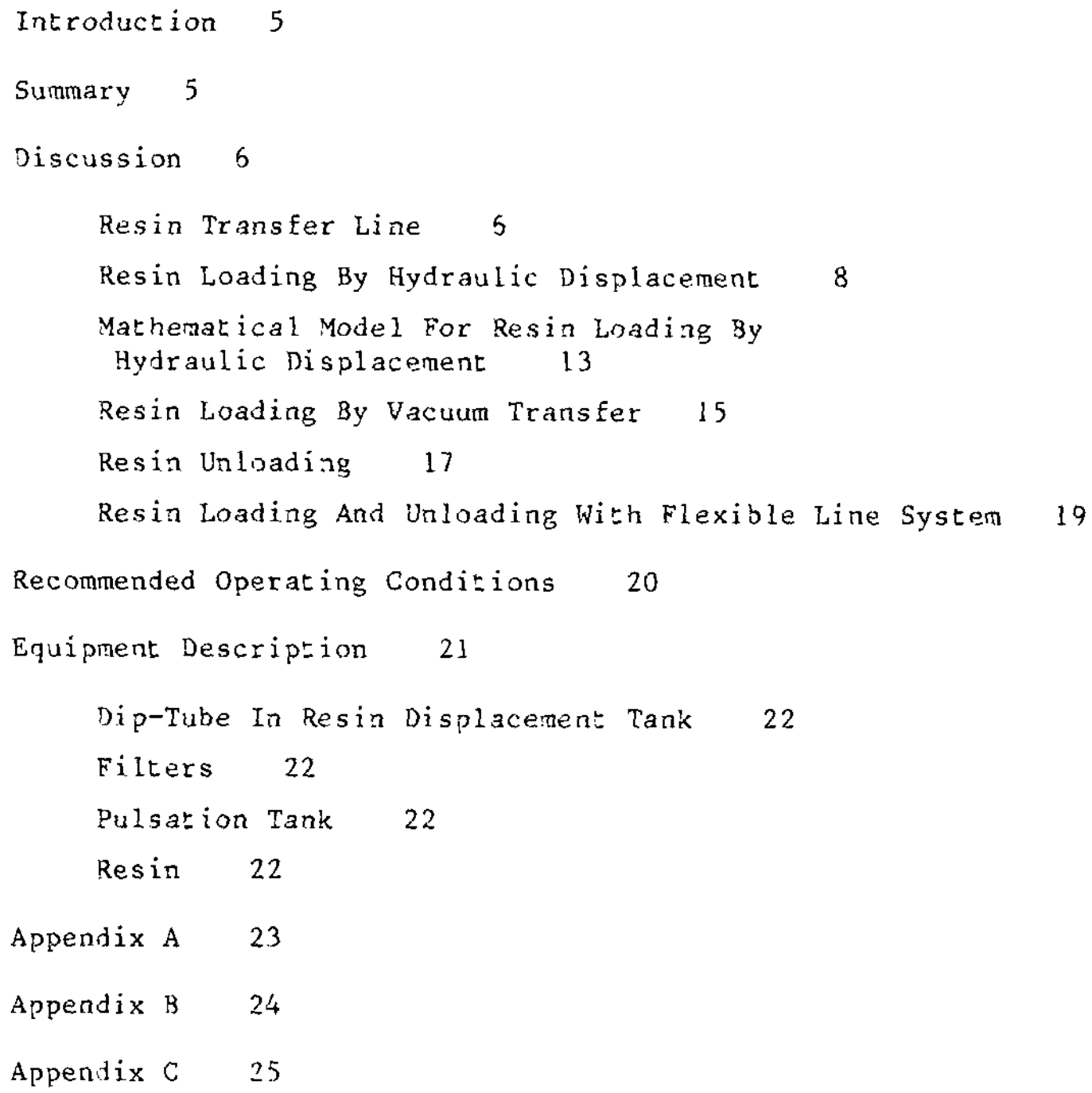


1 Mockup of the MPPF Resin-Transfer Line 7

2 Hydraulic Displacement Resin Loading Process 9

3 Effect of Pressure Drop on Flow for the Fully Loaded 1-, 2-, and 3-inch RIX Columns 11

4 Effect of Pressure Drop on Flow for the Fully Loaded 4-, 6-, and 8-inch RIX Columns 12

5 Lambda Value as Function of the Displacing Fluid Flow 14

6 Vacuum Resin Loading Process 15

7 Resin Unloading Process 18

8 Resin Displacement System 21

\section{LIST OF TABLES}

1 Gravity Transfer of Resin Slurry 6

2 Unplugging Tests 8

3 Maximum and Minimum Displacing Fluid Flows for 100\% Loading of the RIX Columns 10

4 Mathematical Model Lambda Values for the Hydraulic Displacement Process 13

5 Loading Test of the 8-inch RIX Column 16

6 Resin Unloading Data 17

7 Resin Removal with Rigid and Flexible Line Systems 19 


\section{INTRODUCTION}

The Multipurpose Processing Facility (MPPF) is designed to separate and purify transplutonium products. The separation of the transplutonium products is accomplished on Rapid Ion Exchange (RIX) columns loaded with cation exchange resin. Because the solutions to be processed are highly radioactive, the resin deteriorates rapidly and must be replaced after every run. A method was needed for changing the resin without replacing the entire column assembly; the old columns must be removed and new columns loaded with fresh resin are installed. The original concept was to send the old columns containing the spent resin to be buried as high-level waste. However, containers required for long-term retrievable storage of these columns are very expensive. To reduce the cost of replacing the RIX columns and to eliminate possible environmental hazards associated with the disposal of the spent columns, it was proposed that MPPF be modified to permit removal of the spent resin from the columns and loading the columns with fresh resin while the columns remain on the rack. This report describes the tests at the TNX semiworks to develop the resin loading and unloading process.

\section{SUMMARY}

A method for replacing the resin in the columns has been developed at TNX. This method permits the columns to remain on the rack while spent resin is removed from the columns to a resin collection tank and transferred to the rerun evaporator for dissolution. Fresh resin is then loaded into the empty columns from a resin displacement tank in preparation for the next run.

Resin can be loaded into the empty RIX columns by hydraulic displacement or by the combination of vacuum loading followed by hydraulic displacement. In the MPPF, the RIX columns can only be loaded by hydraulic displacement, but the 8-inch RIX column piping will be modified so that it $c$ an be loaded by vacuum. This modification is needed to reduce the size of the resin displacement tank, due to the limited space in the shielded cells, With the use of the vacuum loading process, part of the resin feed (from the third level of the main separations facility) is loaded directly into the column, which eliminates the intermediate path to the displacement tank; therefore, a smaller displacement tank is adequate.

Several techniques were studied at TNX to remove the resin from the RIX columns. Among the resin unloading methods that were investigated at TNX, a resin removal process (for MPPF operation) was selected that requires no changes in the design of the RIX columns and the MPPF piping system. 


\section{DISCUSSION}

\section{Resin Transfer Line}

Before the resin can be loaded, it must be transferred from the third level to the first level of the shielded cells where the resin loading equipment is located. Furthermore, the resin has to be transferred by gravity through a MPPF resin transfer line which consists of 85 feet of $3 / 8$-inch stainless steel tubing.

The MPPF resin transfer line was mocked up at TNX to determine if resin slurry at the desired concentrations could be transferred by gravity through the line. (A schematic of the mocked up MPPF resin transfer line is shown in Figure 1.) Resin slurries of $55 \%$ and $80 \%$ were successfully transferred by gravity through the simulated piping. The results of the gravity transfer tests are shown in Table 1 .

\section{TABLE 1}

\section{Gravity Transfer of Resin Slurry}

$\begin{array}{llll}\begin{array}{l}\text { Resin Slurry } \\ \text { Volume, L }\end{array} & \begin{array}{l}\text { Resin } \\ \text { Concentration, \% }\end{array} & \begin{array}{l}\text { Transfer } \\ \text { Time, min }\end{array} & \begin{array}{l}\text { Average } \\ \text { F1ow, L/min }\end{array} \\ 31.5 & 65 & 29.32 & 1.07 \\ 26.8 & 80 & 46.68 & 0.57\end{array}$

Note: After the transfer of resin slurry is completed, 5 1iters of water is required to remove the residual resin from the transfer line.

Up to an $80 \%$ resin slurry was successfully transferred by gravity through the resin transfer line. Studies also determined a way to unplug the resin transfer line by two tests, the resin transfer line was intentionally plugged with an $80 \%$ slurry. After the resin transfer line had been plugged, process water, at 106 psig was used to unplug the line. In the first test, the secondlevel valve was closed while resin was being transferred, which trapped resin in the upper half of the line. (Some residual resin remained in the lower half of the line when resin transfer was interrupted.) In the second test, the end of the transfer line was capped during resin transfer, which trapped resin in the entire line. The results of the plugging/unplugging tests are shown in Table 2. In both tests, the line was successfully unplugged with pressurized water. 


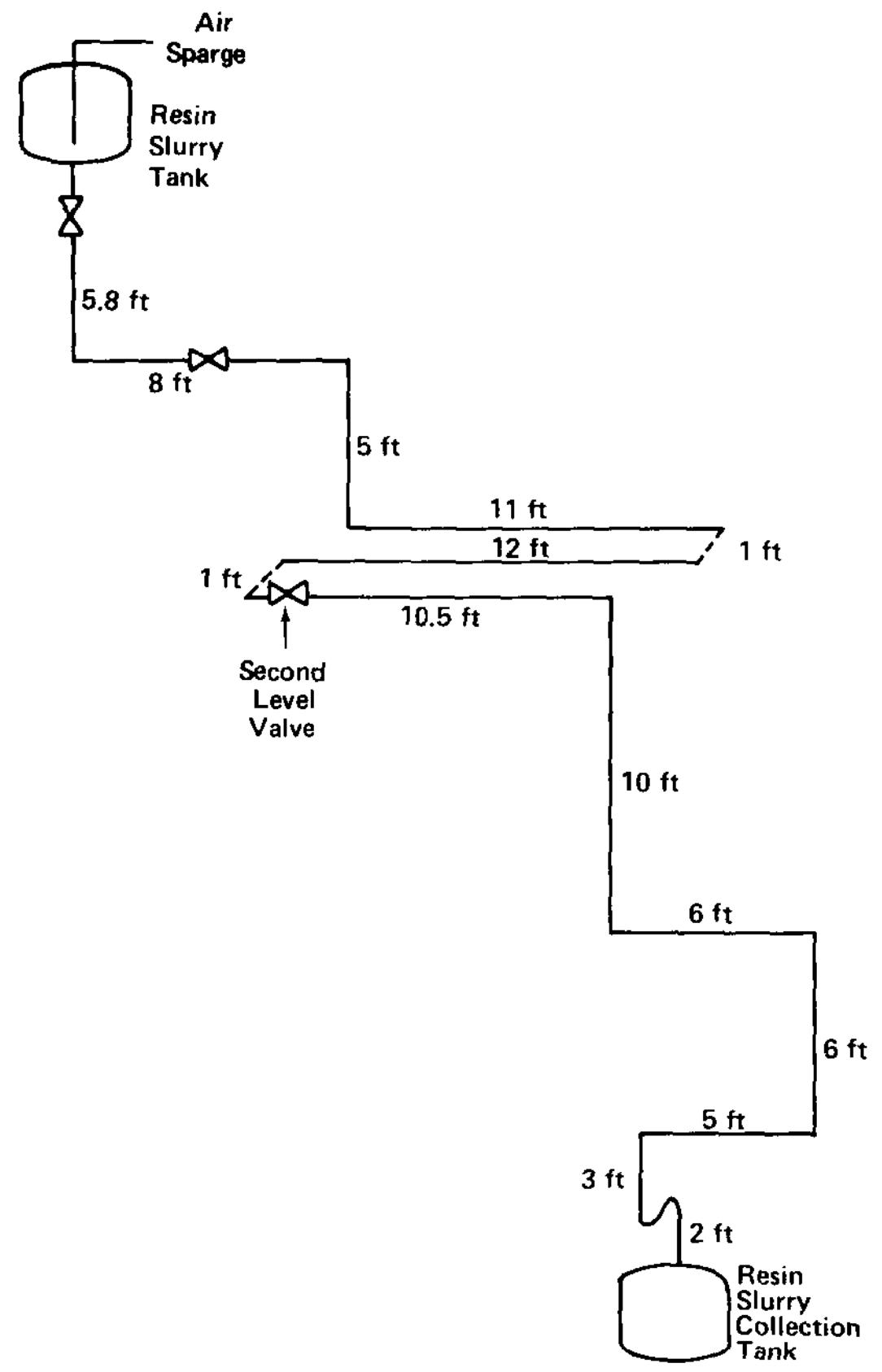

FIGURE 1. Mockup of the MPPF Resin-Transfer Line 
TABLE 2

\section{Unplugging Tests}

Time Required

To Unplug

Tranfer Line, min

5

60
Length of Transfer

Line Which Was

Occupied By Resin

Slurry During Pluggage, ft

$45 *$

$85.5 * *$

* The "Second-Leve1 Valve" was closed while resin was being transferred, trapping resin in the top half of the line. After the resin had remained in the transfer line for one day, process water of 100 psig was used to unplug the line.

** The end of the 1 ine was capped, during resin transfer, trapping resin in the entire line. After the resin had remained in the transfer line for 4 days, process water at 106 psig was used to unplug the line.

\section{Resin Loading By Hydraulic Displacement}

One of the two methods developed to load resin into the RIX columns is the hydraulic displacement process. (A schemat ic of the hydraulic displacement process is shown in Figure 2.) In the first phase of the hydraulic displacement loading process, resin is slurried with water, and then transferred by vacuum into an empty resin displacement tank. When the transfer of resin slurry to the displacement tank is complete, water is pumped into the displacement tank, via a dip-tube, to displace a resin-water mixture into a selected RIX column where the resin is retained between two porous frits. The water portion of the resin-water mixture is allowed to leave the colum through the water line. The flow of the displacing fluid, during loading, is kept constant. As the column becomes loaded the pressure increases rapidly. When the pressure reaches 1000 psig, the first phase of the loading process is complete. Normally greater than $90 \mathrm{vol} \%$ (relative to column's resin retention volume capacity) of the resin is loaded into the column in the first loading period. In the second phase of the displacement process, water is pumped directly. to the top of the column to compact the resin. During compaction, the pressure is maintained between 500 and 700 psig. After one hour, the compaction pressure has reached a relatively stable condition, and compaction is discontinued. In the third phase, resin is reloaded into the RIX column as in phase one. In the final phase, resin inside the RIX 
column is compacted for another hour. After the second hour of compaction, pressure drop across the fully loaded column is reasured at various flows. These pressure drop measurements provide a guideline for MPPF operation to determine whether the columns are fully loaded because the methods used at TNX (described in Appendix A) to determine the amount of resin loaded into the column cannot be used, and the only mean for MPPF operation to determine if the columns are fully loaded with resin is through pressure drop measurements. Figures 3 and 4 show the pressure drops across the fully loaded columns at various flows for the six RIX columns tested at TNX.

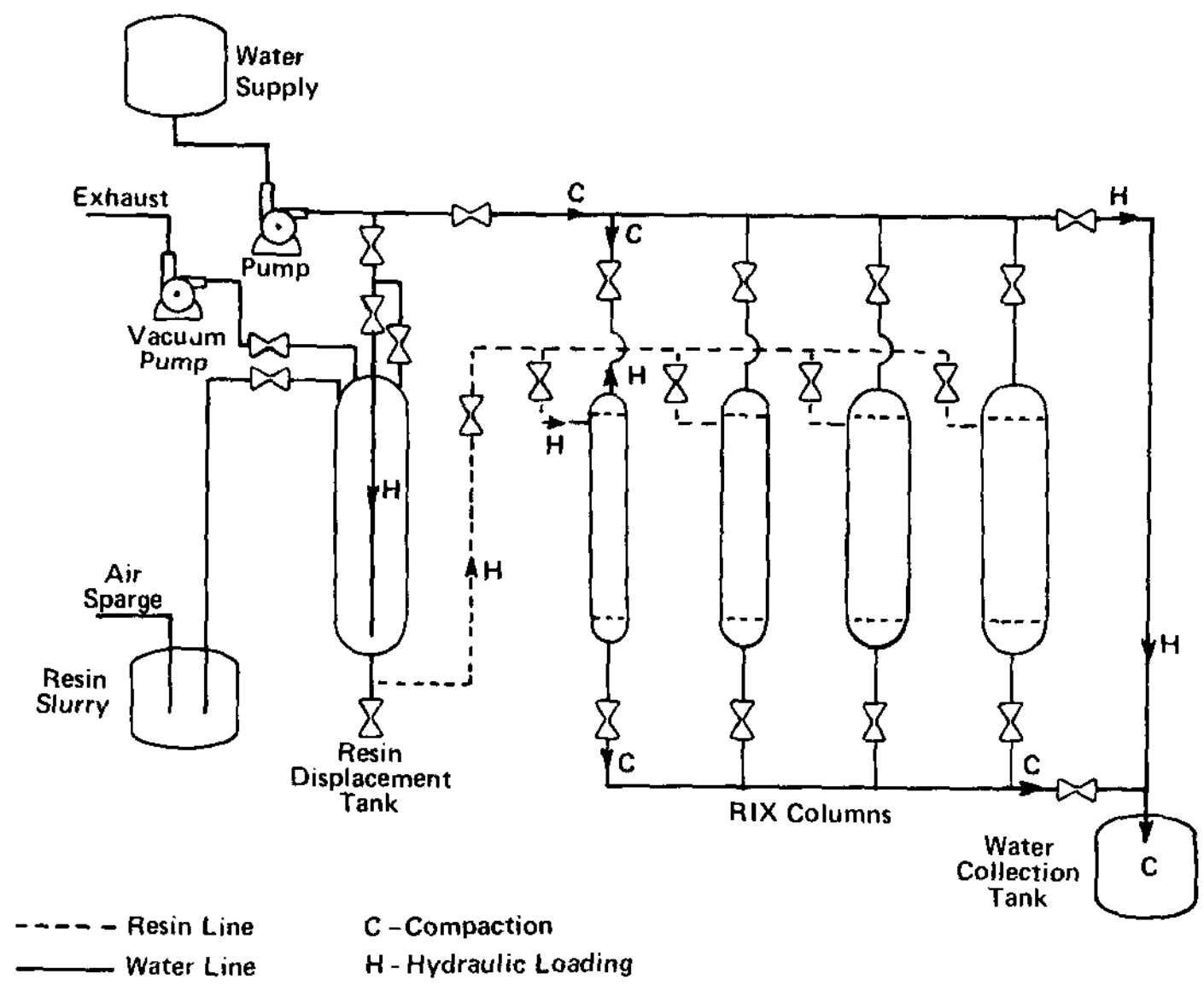

FIGURE 2. Hydraulic Displacement Resin Loading Process. 
The maximum and minimum flow at which the column can be loaded to $100 \%$ design capacity has been determined; test results are shown in Table 3 . However, the tabulated resin loading data are based on a 22-1iter displacement tank which requires that the displacement tank be filled with resin two times to load the 6inch column and four times for the 8-inch column. (A 40-1iter displacement tank is to be used in MPPF.)

TABLE 3

Maximum And Minimum Diaplacing Fluid Flow, for $100 \%$ Loading of The RIX Columns

\begin{tabular}{|c|c|c|c|c|c|}
\hline $\begin{array}{l}\text { Column, } \\
\text { in. } \\
\end{array}$ & $\begin{array}{l}\text { Flow of } \\
\text { Loading, } \\
\text { L/min. }\end{array}$ & $\begin{array}{l}\text { Loading } \\
\text { Time, } \\
\text { (min.) } \\
\end{array}$ & $\begin{array}{l}\text { Flow of } \\
\text { Compaction, } \\
\text { L/min. }\end{array}$ & $\begin{array}{l}\text { Water } \\
\text { Discharged, } * \star \\
\text { L }\end{array}$ & $\begin{array}{l}\text { Resin Volume } \\
\text { Loaded, L*** }\end{array}$ \\
\hline $\begin{array}{l}1^{\prime \prime} \\
1 "\end{array}$ & $\begin{array}{l}0.23 \\
0.75\end{array}$ & $\begin{array}{l}10 \\
3\end{array}$ & $\begin{array}{l}0.5 \\
0.5\end{array}$ & $\begin{array}{l}62.3 \\
62.25\end{array}$ & $\begin{array}{l}0.67 \\
0.67\end{array}$ \\
\hline $\begin{array}{l}2^{\prime \prime} \\
2^{\prime \prime}\end{array}$ & $\begin{array}{l}0.23 \\
3.1\end{array}$ & $\begin{array}{l}28 \\
4\end{array}$ & $\begin{array}{l}0.71 \\
0.71\end{array}$ & $\begin{array}{l}89 \\
97.6\end{array}$ & $\begin{array}{l}2.4 \\
2.4\end{array}$ \\
\hline $\begin{array}{l}3^{\prime \prime} \\
3^{\prime \prime}\end{array}$ & $\begin{array}{l}0.23 \\
3.1\end{array}$ & $\begin{array}{l}50 \\
7\end{array}$ & $\begin{array}{l}1.0 \\
1.2\end{array}$ & $\begin{array}{l}131.5 \\
165.7\end{array}$ & $\begin{array}{l}5.1 \\
5.1\end{array}$ \\
\hline $\begin{array}{l}4^{\prime \prime} \\
4^{\prime \prime}\end{array}$ & $\begin{array}{l}0.23 \\
3.1\end{array}$ & $\begin{array}{l}72 \\
12\end{array}$ & $\begin{array}{l}1.7 \\
1.5\end{array}$ & $\begin{array}{l}213 \\
217.2\end{array}$ & $\begin{array}{l}9.2 \\
9.2\end{array}$ \\
\hline $\begin{array}{l}6^{\prime \prime} \\
6^{\prime \prime}\end{array}$ & $\begin{array}{l}0.23 \\
3.1\end{array}$ & $\begin{array}{l}131 \\
30\end{array}$ & $\begin{array}{l}2.17 \\
2.58\end{array}$ & $\begin{array}{l}284 \\
395\end{array}$ & $\begin{array}{l}19.3 \\
19.3\end{array}$ \\
\hline $\begin{array}{l}8^{\prime \prime} \\
8^{\prime \prime}\end{array}$ & $\begin{array}{l}0.23 \\
3.1\end{array}$ & $\begin{array}{l}106 \\
277\end{array}$ & $\begin{array}{l}3.66 \\
4.46\end{array}$ & $\begin{array}{l}820 \\
497\end{array}$ & $\begin{array}{l}42 \\
42\end{array}$ \\
\hline
\end{tabular}

* Does not include 2 hours of compaction time.

** Water discharge from lóading and compaction.

*** The amount of resin loaded into the RIX column is equivalent to $100 \%$ colum design capacity.

Notes: At a loading rate of $3.5 \mathrm{~L} / \mathrm{rain}$, the loading line experienced pluggage, and no resin was loaded into the RIX column.

$0.23 \mathrm{~L} / \mathrm{min}$ loading tate was the minimum loading rate tested at TNX. Loading rates less than $0.23 \mathrm{~L} / \mathrm{min}$ was not tested due to the extreme length of $t$ ime required to load the RIX column. 


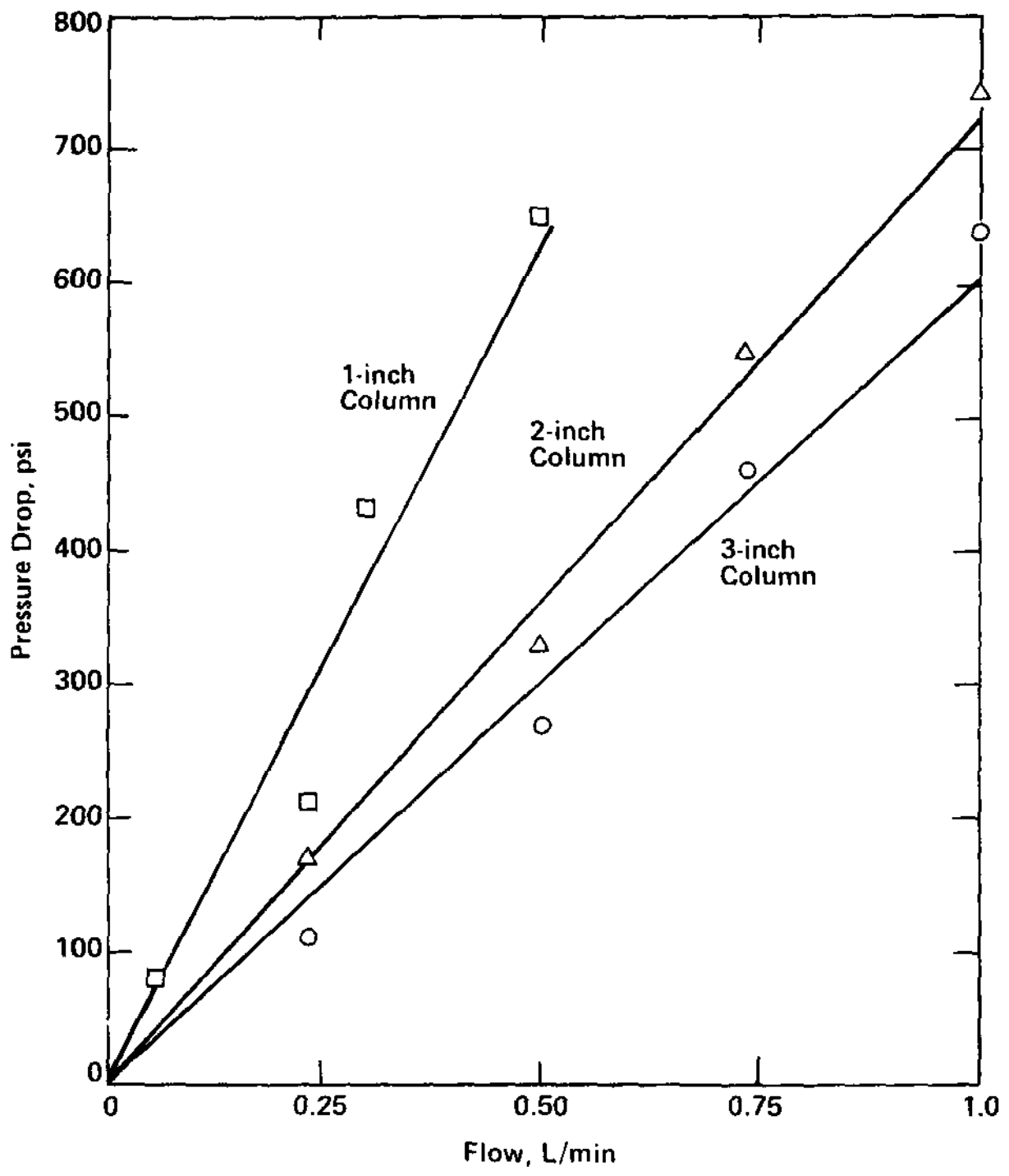

FIGURE 3. Effect of Pressure Drop on Flow for the Fully Loaded $1-, 2-$, and 3-inch RIX Columns 


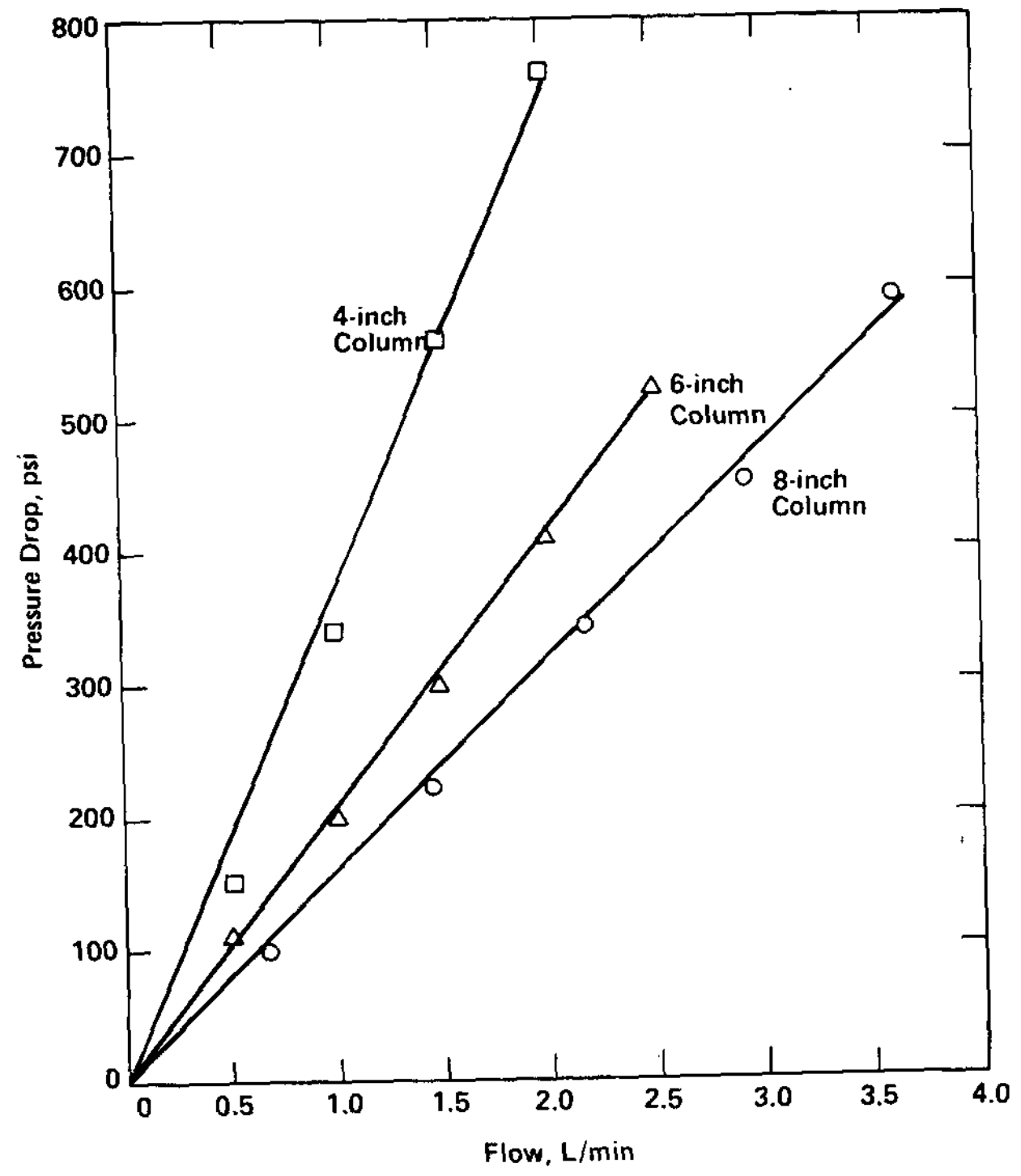

FIGURE 4, Effect of Pressure Drop on Flow for the Fully Loaded 4-, 6-, and 8-inch RIX Columns 


\section{Mathematical Model For Resin Loading By Hydraulic Displacement}

A mathematical model was derived to estimate the time required to load the RIX columns to $100 \%$ capacity. From this mathematical model, Equation 1 was formulated to calculate the time required to load the column to 100\% capacity. (The derivation of Equation 1 is shown in Appedix B.)

$$
t_{100}=\frac{\ln \left[\left(v_{I} / v_{I}-v_{c n}\right)\right]}{\lambda}
$$

where: $t_{100}=t$ ime required to load the column to $100 \%$ capacity

$$
\begin{aligned}
& V_{I}=\text { initial resin volume in the displacement tank } \\
& V_{c n}=\text { volume capacity of the RIX column } \\
& \lambda \quad=\text { a function of flow }
\end{aligned}
$$

The experimental $\lambda$ values for the mathematical model at four different flows are shown in Table 4. Also shown in Table 4 are the calculated $\lambda$ values which represent a perfect mixing condition in the displacement tank, as determined by dividing the volumetric flow of the displacing fluid by the resin displacement tank volume capacity. The ratio of the measured $\lambda$ and calculated $\lambda$ shows the extent of deviation from perfect mixing in the actual resin loading process.

\section{TABLE 4}

Mathematical Model Lambda Values For The Hydraulic Displacement Process

$\begin{array}{llll}\begin{array}{l}\text { Flow, } \\ \text { L/min }\end{array} & \begin{array}{l}\text { Calculated } \\ \text { Lambda, } \\ \text { min-1 }\end{array} & \begin{array}{l}\text { Measured } \\ \text { Lambda, } \\ \text { min-1 }\end{array} & \begin{array}{l}\text { Measured } \\ \text { Calculated }\end{array} \\ 1.0 & 0.045 & 0.062 & 1.38 \\ 1.5 & 0.068 & 0.088 & 1.29 \\ 3.1 & 0.114 & 0.120 & 1.05\end{array}$


A graphic representation of the experimental $\lambda$ values is shown in Figure 5. These results show that at a flow of $2.75 \mathrm{~L} / \mathrm{min}$, mixing is perfect; at flows less than $2.75 \mathrm{~L} / \mathrm{min}$, under-mixing is occurring; and at flows greater than $2.75 \mathrm{~L} / \mathrm{min}$, channeling is occurring.

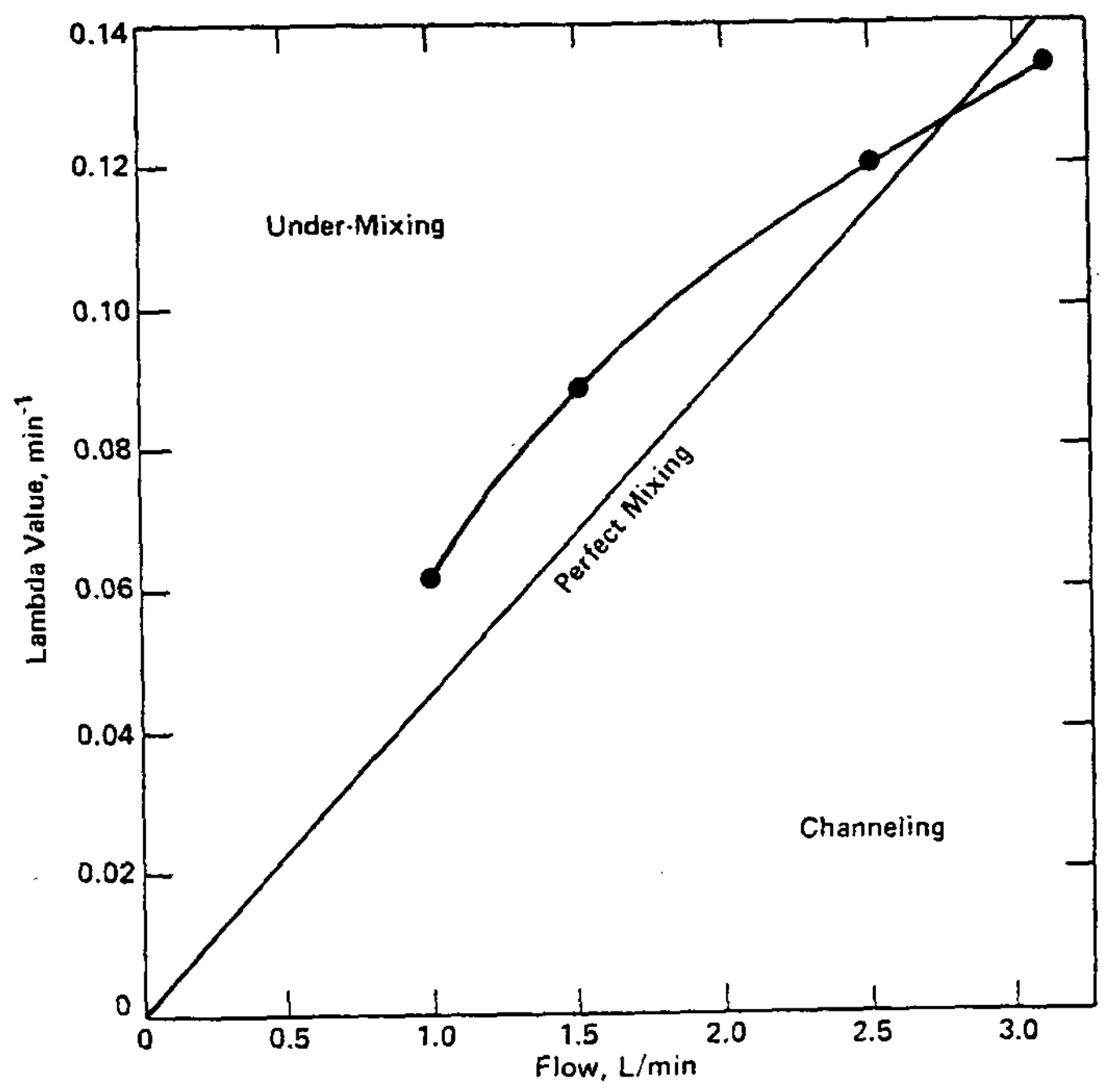

FIGURE 5. Lambda Value as Function of the Displacing Fluid Flow 


\section{Resin Loading by Vacuum Transfer}

Because the space available in MPPF is limited, the resin displacement tank required for the resin loading process is restricted to 40 liters. Furthermore, in the MPPF operation it would be desirable to fill the displacement tank with resin only once to load the 8-inch column. A vacuum resin loading process was developed at TNX to accommodate these needs in MPPF.

In the vacuum resin loading process, resin slurry is loaded into the column by applying a vacuum at the top and bottom of the column. (The column has to be evacuated before vacuum loading can proceed.) The vacuum at the top of the column assists the transfer of resin into the column while the vacuum at the bottom of the column removes a portion of the water in the resin slurry. A schematic of the vacuum resin loading process is shown in Figure 6 .

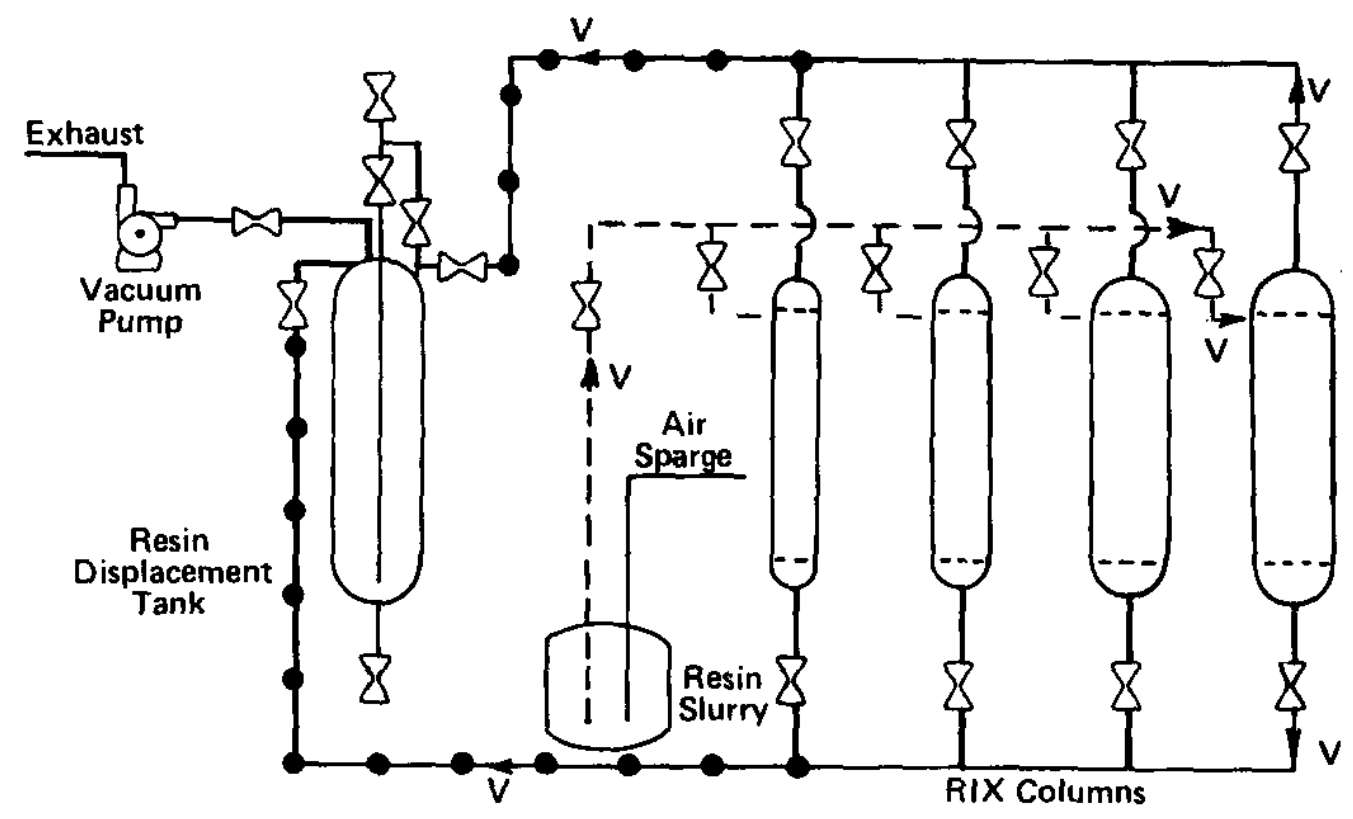

\footnotetext{
- - - Resin Line

Water Line

- Vacuum Line

$\checkmark$ Vacuum Loading
}

FIGURE 6. Vacuum Resin Loading Process 
In a vacuum loading test at the MPPF operational parameters of $65 \%$ resin slurry and an initial vacuum of 18 inches of mercury, the 8 -inch column was loaded to $74 \%$ capacity. The remaining $26 \%$ of resin was then loaded into the colum by the hydraulic displacement process. The results of the combined vacuum loading and hydraulic loading are shown in Table 5 .

TABLE 5

Loading Test of the 8-inch RIX Column

Vacuum Loading

\begin{tabular}{|c|c|c|c|c|c|}
\hline $\begin{array}{l}\text { Loading } \\
\text { Vacuum, } \\
\text { in. Hg }\end{array}$ & $\begin{array}{l}\text { Concent ration } \\
\text { Of Resin } \\
\text { Slurry, } \%\end{array}$ & $\begin{array}{l}\text { Loading } \\
\text { Time, min }\end{array}$ & $\begin{array}{l}\text { Volume of } \\
\text { Resin Slurry } \\
\text { Loaded, L }\end{array}$ & $\begin{array}{l}\text { Volume } \\
\text { Of Resin } \\
\text { Loaded, L }\end{array}$ & $\begin{array}{l}\text { Column } \\
\text { Capacisy, \% }\end{array}$ \\
\hline $14.5^{\star}$ & 65 & 18 & 48 & 31.2 & 74 \\
\hline
\end{tabular}

Hydraulic Displacement Loading

\begin{tabular}{|c|c|c|c|c|c|}
\hline $\begin{array}{l}\text { Flow of } \\
\text { Loading, } \\
\text { L/min }\end{array}$ & $\begin{array}{l}\text { Loading } \\
\text { Time, min }\end{array}$ & $\begin{array}{l}\text { Flow of } \\
\text { Compaction, } \\
\text { L/min }\end{array}$ & $\begin{array}{l}\text { Water } \\
\text { Discharged, L }\end{array}$ & $\begin{array}{l}\text { Resin } \\
\text { Volume } \\
\text { Loaded, L } \\
\end{array}$ & $\begin{array}{l}\text { Column } \\
\text { Capacity, \% }\end{array}$ \\
\hline 3.1 & 28 & 4.0 & 566.8 & 10.8 & 26 \\
\hline
\end{tabular}

* 3.5 inches of $\mathrm{Hg}$ vacuum pressure is lost through the line and air inleakage. (The initial loading vacuum pressure was 18 inches of $\mathrm{Hg}$.)

** Water discharged from loading and compaction. 


\section{Resin Unloading}

In the resin unloading process, water is pumped to the bottom of the column to displace the resin from the column to a resin collection tank 6 feet above the top of the column. During the start of the resin unloading process, a side stream is also introduced to the top of the column to aid the transfer of resin from the column to the resin collection tank. The use of the side stream ( 1 to $2 \mathrm{~min}$ ) is to alleviate the line pluggage problem that often occurs when only the bottom stream is used to displace the resin out of the column. A schematic of the resin unloading process is shown in Figure 7, and the results of the resin unloading tests are shown in Table 6 . Based on these results, the optimum condition for resin removal in MPPF is to unload the spent resin from the RIX columns at the maximum obtainable unloading rate (i.e., $1.0 \mathrm{~L} / \mathrm{min}$ for the 1-, 2-, 3-, and 4-inch columns; 5.0 $\mathrm{L} / \mathrm{min}$ for the 6- and 8-inch columns), because the volume of spent resin and water generated from the resin unloading process and the unloading time is minimized. Furthermore, the total number of resin dissolution runs and the volume of liquid waste produced from the resin dissolution process is also minimized.

TABLE 6

\section{Resin Unloading Data}

\begin{tabular}{llll}
$\begin{array}{l}\text { Column Dia, } \\
\text { inches }\end{array}$ & $\begin{array}{l}\text { Flow of } \\
\text { Unloading, L/min }\end{array}$ & $\begin{array}{l}\text { Unloading } \\
\text { Time, min }\end{array}$ & $\begin{array}{l}\text { Water Required } \\
\text { for Unloading, L }\end{array}$ \\
\cline { 1 - 1 } 1 & 0.5 & 16 & 8 \\
1 & 1.0 & 7 & 7 \\
2 & 0.75 & 16 & 1 \\
2 & 1.0 & 12 & 12 \\
3 & 0.75 & 34.67 & 26 \\
3 & 1.0 & 26 & 26 \\
4 & 0.75 & 40 & 30 \\
4 & 1.0 & 30 & 30 \\
6 & 2.0 & 76 & 152 \\
6 & 3.5 & 32 & 112 \\
6 & 5.0 & 21 & 105 \\
8 & 2.0 & 155 & 310 \\
8 & 3.5 & 80 & 280 \\
8 & 5.0 & 53 & 265
\end{tabular}

Note: The maximum unloading rate in the MPPF facility is $1.0 \mathrm{~L} / \mathrm{min}$ for the 1-, 2-, 3-, and 4-inch columns; the maximum unloading rate for the $6-$ and 8 -inch columns is $5.0 \mathrm{~L} / \mathrm{min}$. 


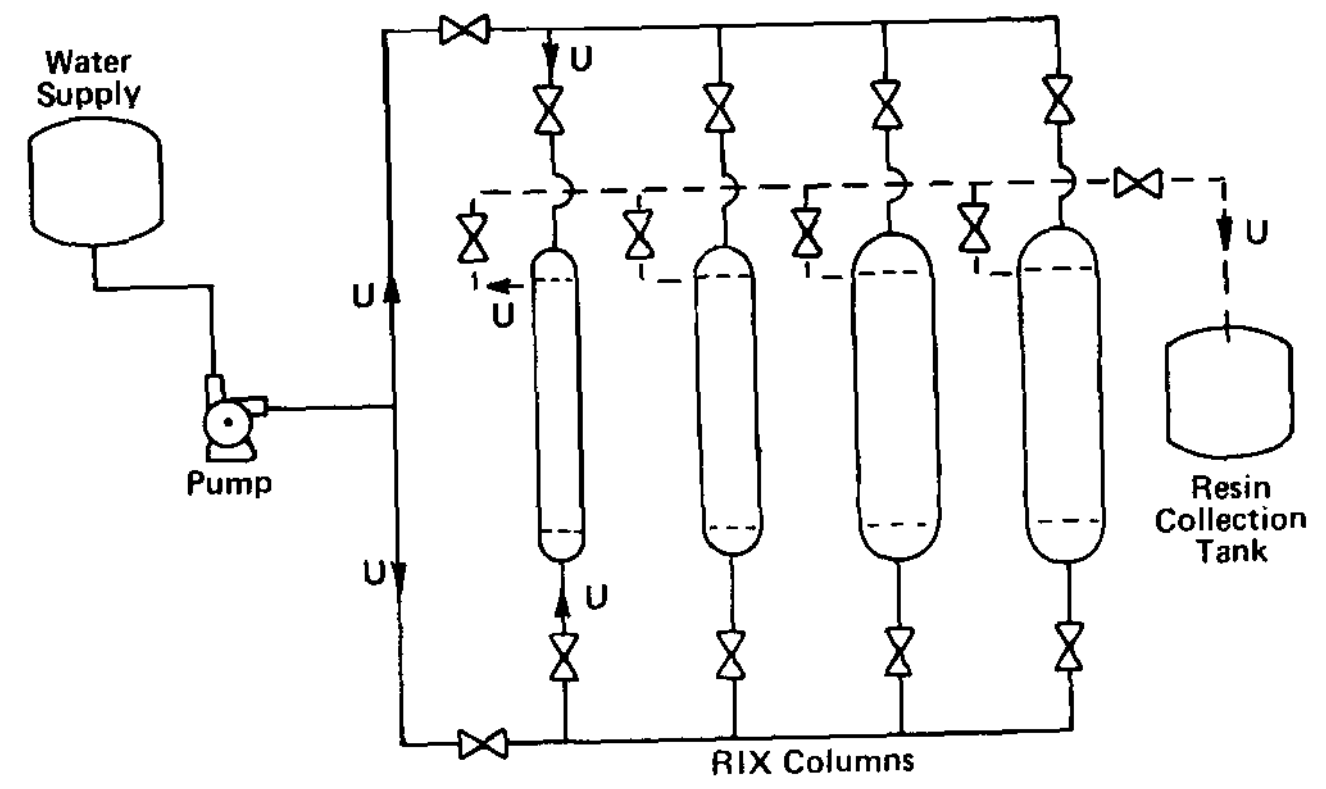

\footnotetext{
- - - Resin Line

Water Line

U Unloading
}

FIGURE 7. Resin Unloading Process 


\section{Resin Loading And Unloading With Flexible Line System}

MPPF would like to use flexible stainless tubing along with quick locking disconnect joints in place of the rigid tubing for the resin addition and removal lines, to permit more operating options in the limited canyon space. The flexible tubing and disconnect joints were installed into the TNX resin displacement system and their performance was tested on the 8-inch column.

The flexible line system performed well for the resin addition, but caused a significant increase in the volume of water required for resin removal. The restriction caused by the quick locking disconnect joints reduced the resin flow out of the column. Normally, the side stream for resin removal is only required for approximately 1 to 2 minutes at the start of the unloading process; however, with the flexible line system, the side stream was required for $1 / 3$ of the resin removal period. Each time the side stream was stopped, the resin tended to plug the line and caused the pump to exceed its operating pressure limit of 1250 psig. The results of resin removal with the flexible line system along with the rigid line system are shown in Table 7.

The significant increase in the volume of water required to unload the resin from the column by the flexible tubing system would increase the total number of resin dissolution runs which in turn would place a severe (and unnecessary) load on the resin dissolution equipment. Therefore it is not advantageous to use the flexible tubing system for resin removal; however, the flexible tubing without the quick locking disconnect joint can replace the rigid tubing without any adverse effects.

\section{TABLE 7}

\section{Resin Removal With Rigid And Flexible Line Systems}

\begin{tabular}{llll}
$\begin{array}{l}\text { System Used } \\
\text { For Resin } \\
\text { Removal }\end{array}$ & $\begin{array}{l}\text { Flow of } \\
\text { Unloading, L/min }\end{array}$ & $\begin{array}{l}\text { Unloading } \\
\text { Time, min }\end{array}$ & $\begin{array}{l}\text { Water Required } \\
\text { For Unloading, L }\end{array}$ \\
\cline { 2 - 4 } Rigid & 5.0 & 53 & 265 \\
Flexible & 5.0 & 78 & 390
\end{tabular}




\section{RECOMMENDED OPERATING CONDITIONS}

During the separation of the transplutonium element in the MPPF operation, the resin is damaged by iradiation. The irradiated resin can then plug the RIX column frit as follows: 1) the irradiated resin can adhere to the RIX column frit and seal the pores of the frit; 2) resin that is fragmented (by radiation) can implant into the pores of the RIX column frit. When the frit is plugged, the water removal surface area of the frit is decreased. The plugged frit would impede the removal of water from the column during the resin loading process; consequently, the range of loading rates at which the column can be loaded to $100 \%$ design capacity is reduced. Therefore, to ensure that the RIX column is fully loaded with resin without increasing the loading time significantly, as much resin as possible should be loaded into the RIX column at the maximum loading rate in the first loading period, and the resin loading completed at a lower loading rate.

The optimum condition for resin removal in MPPF is to unload the spent resin from the RIX columns at the maximum obtainable unloading rate (i.e., $1.0 \mathrm{~L} / \mathrm{min}$ for the 1-, 2-, 3-, and 4-inch columns; $5.0 \mathrm{~L} / \mathrm{min}$ for the $6-$ and 8 -inch columns), because the volume of spent resin and water generated from the resin unloading process, and the unloading time is minimized. Furthermore, the total number of resin dissolution runs and the volume of liquid waste produced from the resin dissolution process is also minimized. However, if the column frit is partially plugged, MPPF may not be able to use the maximum unloading rate to remove the resin from the RIX columns. The partially plugged frit would inhibit the flow of water into the column, and could cause the pump to exceed its operating pressure limit. In this case, MPPF should use the highest flow that the pump operating pressure limit would allow to remove the resin from the column.

As the resin is being irradiated, the resin particles can agglomerate. If the size of the agglomerated resin exceeds the opening of the resin removal line, then the resin cannot be unloaded from the RIX column, and the column would have to be replaced. Currently, dissolving the resin inside the RIX column is being studied. If this resin dissolution technique is successful, the agglomerated resin inside the RIX column could be dissolved, and the RIX column would not have to be replaced. 


\section{EQUIPMENT DESCRIPTION}

Six standard RIX columns 1-, 2-, 3-, 4-, 6-, 8-inch-diameter, were used for the tests. The design specifications for the RIX columns are shown in Appendix C. Water was supplied from a 50 liter plastic bottle and pumped to the columns by parallel Milroyal $B$ and $C$ pumps. Resin was slurried from a 50-1iter plastic bottle and transferred to the cylindrical 22-liter resin displacement tank by vacuum. The resin displacement tank was modified as discussed in the "Dip-Tube in Resin Displacement Tank" section. Resin was removed to an elevated resin collection tank 6 feet above the top of the columns. A schematic of the resin displacement system is shown in Figure 8 .

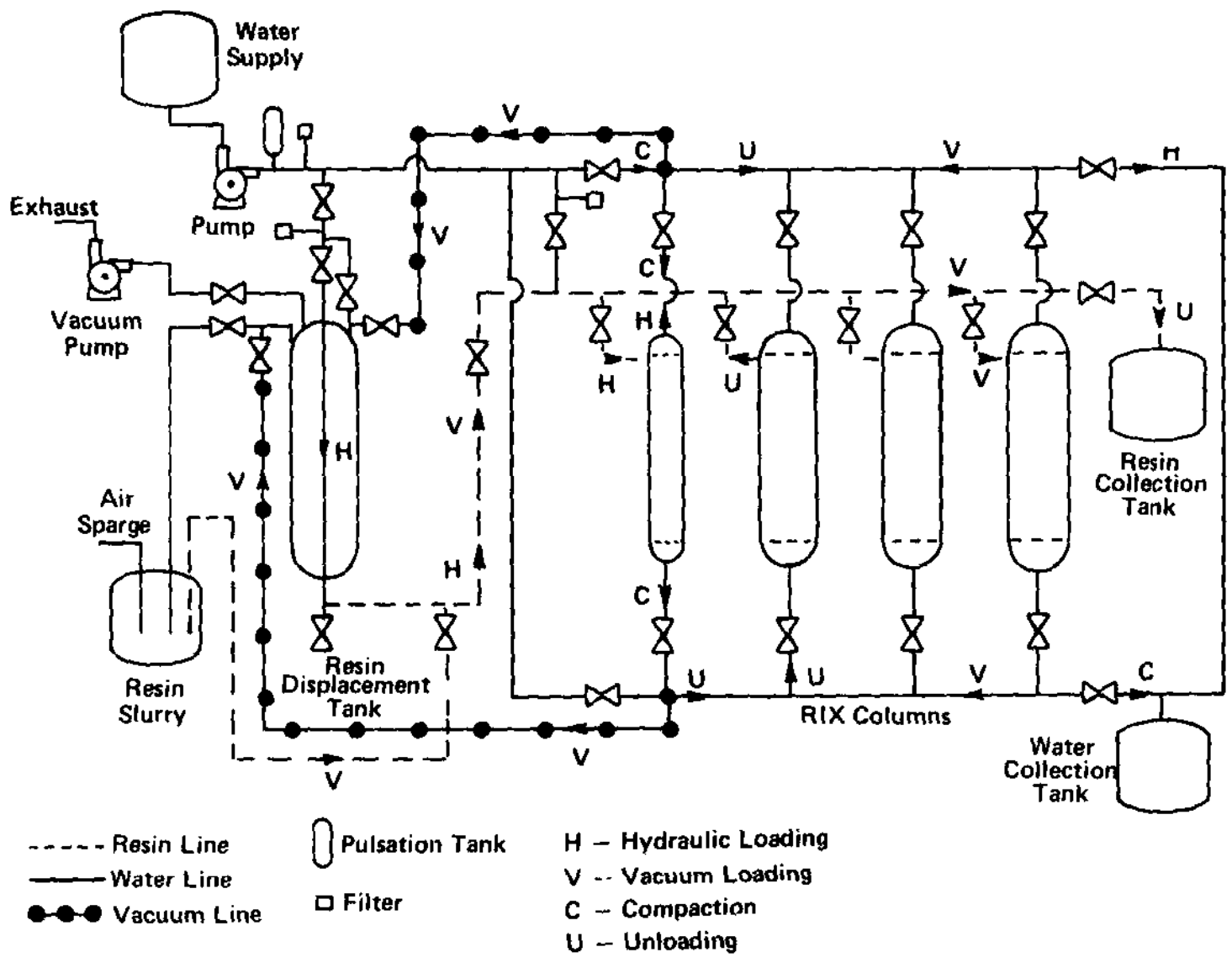

FIGURE 8. Resin Displacement System 


\section{Dip-Tube In Resin Displacement Tank}

Loading the columns by simply pumping water into the top of the resin displacement rank and displacing resin from the bottom of the tank to the appropriate RIX column resulted in a partial pluggage of the loading line and incomplete column loading. A dip-tube was installed on the water inlet to the resin displacement rank so that the resin was agitated and suspended by the water addition. Furthermore, the dip-tube ( 1 inch from the tank bottom) increased the range of flows at which the columns can be fully loaded. With the dip-tube, for example, the 4 -inch column can be loaded to $100 \%$ capacity at a flow of $3.1 \mathrm{~L} / \mathrm{min}$. Without the diptube, the 4-inch colum can only be loaded to $67 \%$ capacity at a flow of $0.75 \mathrm{~L} / \mathrm{min}$.

\section{Filters}

Two of the three filters installed in the resin displacement system are used to prevent resin from entering the water line. One of the resin filters is located at the junction of the dip tube and the water 1 ine to prevent resin from backwashing into the water line. The second resin filter is located at the junction of the resin line and the water line. It is used to confine the resin in the resin line when the water is needed for cleaning the resin line. The third filter is a water filter which is used to remove any foreign substances that may be in the water supply. The location of this filter is at the pump discharge.

\section{Pulsation Tank}

A pulsation :ank was installed in the resin displacement system to reduce the high pressure fluctuation during the loading and unloading process. The pulsation tank is located at the water pump discharge upstream of the water filter.

\section{Resin}

The resin used for the tests was Dowex ${ }^{(1)} 50 \mathrm{~W}-\mathrm{X} 8$ (Trademark of Dow Chemical Company). The particle size of the resin ranges from 60 to 100 microns, and the age of the resin is approximately 7 years or older. 


\section{APPENDIX A}

Techniques Used To Determine The Amount of Resin Loaded In The RIX Column Relative To The Column Design Capacity

1. $\%$ D.C. $=\frac{\mathrm{V}_{\mathrm{A}} \mathrm{X}_{\mathrm{A}}-\mathrm{V}_{\mathrm{B}} \mathrm{X}_{\mathrm{B}}}{\text { Column Design Capacity }}$

$v_{A}=$ Make-up Volume Transferred to Resin Displacement Tank

$\mathrm{x}_{\mathrm{A}}=\%$ Resin in Make-up Volume

$V_{B}=$ Residual Volume in Resin Displacement Tank

$X_{B}=\%$ Resin in Residual Volume

2. \% D.C. $=\frac{v_{C} X_{C}}{\text { Column Design Capacity }}$

$\mathrm{V}_{\mathrm{C}}=$ Total Volume Discharged from Column Unloading

$\mathrm{X}_{\mathrm{C}}=\%$ Resin in Discharged Volume 


\section{APPENDIX B}

\section{Derivation of The Mathematical Model For Hydraulic Displacement}

\section{Resin Loading}

From experimental data, the amount of resin in the displacement tank as function of time can be expressed in terms of Equation 1.

$$
V_{T}=V_{I} e^{-\lambda t}
$$

where: $\quad V_{T}=$ resin volume in the displacement tank at $t$ ime $t$

$$
\begin{aligned}
& V_{I}=\text { initial resin volume in the displacement tank } \\
& \lambda=\text { function of flow } \\
& t=\text { rime }
\end{aligned}
$$

Therefore, the amount of resin loaded into the RIX column can be evaluated by the difference between the initial and final resin volumes in the displacement tank.

$$
\begin{aligned}
& v_{C}=v_{I}-v_{T} \\
& v_{C}=v_{I}-v_{I} e^{-\lambda t} \\
& v_{C}=v_{I}\left(1-e^{-\lambda t}\right)
\end{aligned}
$$

where $V_{C}$ is the resin volume loaded into the column

Hence, the time required to load the column to $100 \%$ capacity can be calculated with the following equations.

$$
\begin{aligned}
& t_{100}=\frac{\ln \left(1-\frac{v_{c n}}{v_{I}}\right)}{-\lambda} \\
& \left.t_{100}=\frac{\ln \left(\frac{v_{I}}{v_{I} v_{c n}}\right)}{\lambda}\right)
\end{aligned}
$$

$t_{100}=t$ ime required to load the column to $100 \%$ capacity

$$
\mathrm{v}_{\mathrm{cn}}=\text { volume capacity of the column }
$$




\begin{tabular}{lllll}
$\begin{array}{l}\text { APPENDIX C } \\
\text { Column Design Specifications }\end{array}$ & & \\
$\begin{array}{l}\text { Nomina1 } \\
\text { Diameter, } \\
\text { inches }\end{array}$ & $\begin{array}{l}\text { Inside } \\
\text { Diameter, } \\
\text { inches }\end{array}$ & $\begin{array}{l}\text { Frit } \\
\text { Diameter, } \\
\text { inches }\end{array}$ & $\begin{array}{l}\text { Length Between } \\
\text { Plugs, inches }\end{array}$ & $\begin{array}{l}\text { Capacity } \\
\text { Between } \\
\text { Plugs, L }\end{array}$ \\
\hline 1 & 1.049 & 0.725 & 48 & 0.67 \\
2 & 1.939 & 1.595 & 48 & 2.4 \\
3 & 2.900 & 2.531 & 48 & 5.1 \\
4 & 3.826 & 3.470 & 48 & 9.2 \\
6 & 5.625 & 5.040 & 48 & 19.3 \\
8 & 7.375 & 6.575 & 60 & 42.0
\end{tabular}

